\title{
Women's International Human Rights Law: The Way Forward
}

\author{
Rebecca Cook
}

\author{
Version Publisher's Version \\ Citation Rebecca Cook, "Women's International Human Rights Law: The Way \\ (published version) Forward" (1993) 15 Human Rights Quarterly 230.
}

Copyright / License Copyright (C) 1993 The Johns Hopkins University Press. This article was first published in Human Rights Quarterly 15:1(1993), 230. Reprinted with permission by Johns Hopkins University Press.

\section{How to cite TSpace items}

Always cite the published version, so the author(s) will receive recognition through services that track citation counts, e.g. Scopus. If you need to cite the page number of the author manuscript from TSpace because you cannot access the published version, then cite the TSpace version in addition to the published version using the permanent URI (handle) found on the record page.

This article was made openly accessible by $U$ of 'T Faculty. Please tell us how this access benefits you. Your story matters. 


\section{Women's International Human Rights Law: The Way Forward}

Rebecca J. Cook*

\section{TABLE OF CONTENTS}

I. Introduction

II. Progress, Challenges, and Prospects 232
A. Why Rights?

B. Whose Rights?

C. How to Legitimize Rights in Different Cultures 235

III. Making International Human Rights Law

Gender Conscious

A. Recharacterizing Nondiscrimination Rights 238

B. Recharacterizing Civil and Political Rights 242

C. Recharacterizing Economic, Social and Cultural Rights: The Problem of Structural Adjustment

IV. Guaranteeing Specific Human Rights of Women

A. The Nationality Problem

B. Discriminatory Personal Law

C. Customary Property Law

D. Reproductive Rights

E. Violence Against Women

\footnotetext{
* I am grateful to the participants whose insights, perspectives and experiences reflected in their papers and consultation contributions have made this report possible, to Karen Knop for her extensive help in the preparation of this report, to Julia McNally and Valerie Oosterveld for their note taking during the consultation and subsequent research assistance, to Heather Gamester for her tireless organizational efforts and to June Zeitlin of the Ford Foundation who funded the consultation. I am alone responsible for the contents of this report.
} 
V. Working With What We Have: Making International Human Rights Law More Effective for Women

A. State Responsibility for Violations of Women's Rights 250

B. International Protection

1. Treaty based Bodies

2. Charter based Bodies

254

C. Regional Protection

256

D. Domestic Protection

258

VI. Conclusion: Common Denominators

\section{INTRODUCTION}

International human rights law has not yet been applied effectively to redress the disadvantages and injustices experienced by women soley because of their gender. In this sense, respect for human rights fails to be "universal." The reasons for this general failure to enforce women's human rights are complex and vary from country to country. These reasons include a lack of understanding of the systemic nature of the subordination of women; the failure to recognize the need to characterize the subordination of women as a human rights violation; and a lack of state practice to condemn discrimination against women. Moreover, traditional human rights groups have been unwilling to focus on violations of women's rights, and women's groups have not understood fully the potential of international human rights law to vindicate women's rights.

This article is a report of a consultation of lawyers from Africa, the Americas, Asia, Australia, and Europe held at the University of Toronto Faculty of Law, in August 1992. The participants brought legal theory and practice to bear on the relationship between international human rights and women's rights in order to develop legal strategies to promote and protect women's international human rights. Although this article is a report of that consultation, it is by no means the report as there are as many reports as participants. However, the real impact of the event will be realized only when the findings of the consultation are used to prevent, investigate, and punish violations of women's human rights.

The purpose of this report is to offer some idea of the multiple perspectives that emerged on the consultation themes. The themes were:

i. to review the progress of women's rights and identify challenges and prospects;

ii. to recharacterize internationally protected human rights to accommodate women's experiences of injustice;

iii. to guarantee specific human rights of women; and 
iv. to make international human rights law more effective for women.

The papers presented at the consultation (as amended in response to discussion following presentation) will form the basis of a forthcoming book on Women's International Human Rights Law.

\section{PROGRESS, CHALLENGES, AND PROSPECTS}

\section{A. Why Rights?}

Hilary Charlesworth, now of the University of Adelaide Faculty of Law, opened the consultation by raising a fundamental question:

Do legal rights really offer anything to women? Women's disadvantages are often based on structural injustice and winning a case in court will not change this.

Her answer was that, "[b]ecause women in most societies are starting in such a disadvantaged position, rights discourse offers a significant vocabulary to formulate political and social grievances which is recognized by the powerful."

Celina Romany, City University of New York Law School, answered the question in another way. She said that rights could be far more powerful if women were not limited by the ways in which men talk about rights, and she encouraged women to make "rights talk" their own. She explained that rights are defined by who talks about them, the language that is used, and the process of talking about them. She recommended that women, their language, and their ways of talking about their experiences of injustice need to make a far greater contribution to the development of international human rights law. Participants agreed that many more women, and women from many diverse backgrounds, should talk about the content that should be added to women's rights. Andrew Byrnes, University of Hong Kong Faculty of Law, proposed that we need to make "a concerted effort to expand the range of participants in that dialogue, and to wrest some of the power of defining and speaking from narrow androcentric models to address issues of central concern to women."

Other participants questioned the validity of the rights discourse. Adetoun llumoka, a legal practitioner from Lagos, Nigeria, said that the rights discourse in Africa is not meaningful since the severity of socio-economic problems faced by women in countries undergoing structural adjustment may require a basic needs strategy rather than a rights strategy.

Radhika Coomaraswamy, of the International Centre for Ethnic Studies in Colombo, Sri Lanka, said that in Asia the rights discourse is weak, in part because it privileges free, independent women, whereas Asian women tend to be attached to their communities, castes, or ethnic groups. 
The consultation adopted the working presumption that there should be a relationship between international human rights and women's rights. However, no one lost sight of the limitations of a rights strategy and the fact that its effectiveness would vary from culture to culture. Participants stressed the importance of expanding understanding of the context of women's subordination, especially where oppression is exacerbated by poverty or ethnic status, and agreed that the means chosen to combat discrimination will need to be varied according to its particular contexts. Asma Halim, a legal practitioner from Khartoum, Sudan, observed that while the nature of subordination, and thus the means to combat it, may vary, "we must not lose sight of the fact that we are subordinated because we are women" and that the goal of eliminating all forms of subordination of women remains universal.

\section{B. Whose Rights?}

In determining whether recharacterization might be effective to protect women's rights internationally, Charlesworth raised a second fundamental question that pervaded discussions at the consultation:

Can women's rights be universal? Put another way, is the idea of women's international human rights, premised as it is on the fact that women worldwide suffer from patriarchy, misconceived? Is the pervasive devaluation of women's lives enough to link women in the effort to add a gender dimension to international human rights?

Charlesworth sketched three feminist approaches that might serve to recharacterize rights in order to make them more universally applicable by better accommodating women's pervasive experiences of injustice:

1) Liberal feminism attempts to realize the equal treatment guaranteed by existing law, and thereby discounts intrinsic differences between men and women. A problem with this approach is that it fails to understand the structural imbalance of power between men and women and the systemic nature of discrimination.

2) The goal of cultural feminism is to celebrate the differences between masculine and feminine ways of reasoning. This approach may lead to marginalization of women's rights because presenting them as different from men's needs may induce the response that they are less worthy of resources.

3) The purpose of radical feminism is to transform the masculine world where inequality is based on systemic domination and subordination of women by men. This approach is problematic strategically when it requires revolutionary change in a conservative community that is ready at most for evolutionary change.

Participants agreed that these approaches or a mix of them might be useful in recharacterizing international human rights law to be more responsive to 
the degradation of women. ${ }^{1}$ However, they cautioned that feminist recharacterization of law in one type of society cannot be imported wholesale either into other types of societies or into the international human rights system.

The distinction between the public and private sectors of society offers an example of the insights and pitfalls of applying Western feminist theories to other social and legal systems. This distinction, long a target of feminist critiques in Western liberal societies for masking women's oppression, may manifest itself to different effects in other societies, and may illuminate areas of otherwise unobserved subordination. Charlesworth explained that "what is public in one society may well be private in another," but that, regardless of whether a matter is considered public or private, the women's domain is consistently devalued.

The public/private distinctions can be perceived in at least two ways. In the first, the public sector of legal and political order is contrasted with the private sector of home and family, where regulation is deemed inappropriate. Charlesworth noted that this distinction is gendered because women operate in the private sector, where abuses such as domestic violence and degradation are invisible and unregulated by the law. The second is similar to public and private ownership. The public sector is comprised of the state and its agencies, and the private sector is composed of the vast array of nonstate activities.

Manfred Nowak, of the Federal Academy of Public Administration, Vienna, Austria, thought that the second distinction is more important to international human rights law because it corresponds to the classical theory of state responsibility for human rights violations. The classical theory requires the state to provide effective protection and remedies against human rights violations. International law of state responsibility compels governments to respect, ensure, and protect women's international human rights, and that when they fail to do so, sanctions can be imposed. International law doctrine now goes beyond the classical state duty not to interfere with individual human rights and holds states accountable for not acting positively to ensure rights. ${ }^{2}$ Moreover, Nowak explained, international law now ob-

1. See generally, Charlotte Bunch, Women's Rights as Human Rights: Toward a Re-Vision of Human Rights, 12 Hum. Rts. Q. 486 (1990); Andrew Byrnes, Women, Feminism and International Human Rights Law-Methodological Myopia, Fundamental Flaws or Meaningful Marginalization? 12 Australian Y.B. Int'I L. 205 (1992); Hilary Charlesworth, Christine Chinkin \& Shelley Wright, Feminist Approaches to International Law, 85 Am. U. J. Int'l L. \& Pol'y 613 (1991); Rebecca J. Cook, Women's International Human Rights: A Bibliography, 24 N.Y.U. J. Int'l L. \& Pol. 857 (1992).

2. Airey v. Ireland, 32 Eur. Ct. H.R. (ser.A) (1979) (responsible for not having taken the necessary positive steps to ensure a woman's access to courts to secure a separation from her abusive husband); $X$ and $Y v$. the Netherlands, 91 Eur. Ct. H.R. (ser. A) (1985)(responsible for not having enacted appropriate criminal legislation to vindicate the rights of a mentally handicapped girl who had been raped). 
ligates states to use due diligence to prevent, investigate, and punish systemic and egregious human rights violations between private actors. ${ }^{3}$ Nowak acknowledged that state responsibility for individual abusers applies at a level only one step removed from the abuser's wrongdoing, but he argued that this limitation follows from the general nature of international law, not from any gender bias.

Charlesworth responded to this argument by wondering whether, had women been more influential in the development of international law, they would have constructed it more readily to reach violations of human dignity that dominate women's lives, such as domestic violence.

\section{How to Legitimize Rights in Different Cultures}

A third fundamental question discussed throughout the consultation was:

How can universal human rights become legitimized in radically different societies without succumbing to either homogenizing universalism or the paralysis of cultural relativism?

Coomaraswamy analyzed the barriers to "indigenizing" rights in South Asia. She emphasized the need to avoid the "Orientalist trap" of dividing the world in bipolar categories. Those in the West must guard against the idea that the West is progressive on women's rights and the East is barbaric and backward. Those in the East must be equally cautious not to subscribe to the inverse notion that accepts the East/West distinction but views the East as superior, more communal, and less self-centered with no place for an "adversarial" concept of rights. She cited the coexistence of both traditions in South Asia to illustrate the dangers of oversimplification.

Coomaraswamy started from the presumption that, for human rights to be effective, they must become a respected part of the culture and traditions of a given society. In South Asia, the institution of law is generally viewed with deep suspicion and often hatred because it is seen as the central instrument employed by colonizing powers to replace indigenous cultural, religious, and social traditions with the mechanisms of the modern Western nation state.

When the law of women's human rights is associated with an impersonal and homogenizing Western state, the rights are discredited. Coomaraswamy

3. Velasquez Rodriguez v. Honduras, Judgment of 29 July 1988, Inter-Am. C.H.R., OAS/se. LN NIII.19, doc. 13 (1988) (responsible for not using the organs of state to prevent, investigate and punish disappearances perpetrated by private actors); Herrera Rubio v. Colombia, Comm. No. 161/1983, U.N. Doc. CCPR/C/OP/2, at 192 (1983) (responsible for failure to take appropriate measures to prevent disappearances and subsequent killings and failure to take measures to remedy violations of denial of liberty and dignity of person). 
proposed that the future of human rights in the South Asia region does not lie with the state, but with the confluence of the interests of the state and movements in civil society. She cautioned that "unless human rights values take root in civil society and unless civil institutions and non-governmental organizations (NGOs) take up the cause, then women's rights as human rights will have no resonance in the social institutions concerned."

She cited the case of Roop Kanwar, a university student who was burnt alive on her husband's funeral pyre in Deorala, Rajasthan, as an example of the dissonance between women's rights and ethnic identity, explaining that:

Urban centered women's groups as well as groups of women from all over India were horrified, and organized a march in Rajasthan. The Rajasthanis retaliated and filled the streets with thousands of their own ethnic groups claiming that the right to commit sati was part of their ethnic culture. After months of waiting, the police finally arrested Roop's father-in-law and five other members of the family for abetment to suicide. Three months later, the Indian Parliament passed a tough law banning sati, even though an old law already existed, as a sign of central government intolerance of these ethnic practices.

In reflecting on the outcome of the case, Coomaraswamy observed that:

Though the feminist movement had scored some type of legal victory, the case pointed to the terrible gulf between human rights and women's rights activists, on the one hand, and those who see the status of women as an integral part of their ethnic identity, on the other hand.... What is the point of all these laws if the people do not believe that putting an eighteen-year-old woman on a funeral pyre and denying her life is not a violation of the most basic fundamental right-the right to life? What is the point of all the Constitutional protection if "ethnic identity" is an acceptable justification for reducing the status of women according to diverse cultural practice?

Coomaraswamy pointed out that, in contrast to ethnic practices that deny women their basic human rights, there are social movements and traditional ideologies that have been used to enhance women's status. She suggested that rights discourse will have more resonance and therefore more effectiveness when it can "plug into many of the dynamic social movements taking place in South Asia." According to Coomaraswamy, Asian women activists argue that "legal strategies to emancipate women need to allow women to touch base with their traditional sources of empowerment."

Abdullahi An-Na'im, a Sudanese Scholar-in-Residence at the Ford Foundation's Cairo office, underscored the importance of cultural legitimacy of international human rights. He explained that if cultural legitimacy is not taken seriously, "it is sometimes raised with the intention of undermining international human rights law, or of justifying its violation." It is not enough, he said, to rely on international law obligations to bring national laws, 
including religious and customary laws, into compliance with international human rights principles. International law, he explained, "is fully consistent with state sovereignty... since it simply seeks to ensure that states effectively fulfil legal obligations which they have already assumed under international law."

An-Na'im suggested that one must go beyond this formalistic understanding of international legal obligations in order to seek a deeper consensus and sustainable commitment to women's international human rights. ${ }^{4} \mathrm{He}$ argued that unless international human rights have sufficient legitimacy within particular cultures and traditions, their implementation will be thwarted, particularly at the domestic level, but also at the regional and international levels. Without such legitimacy, neither the law nor other agents of social change will be capable of improving the status of women.

He suggested stimulating "internal discourse" and "cross cultural dialogue" on the issue of women's legal status and rights. "Internal discourse" between different sectors of society that hold different views on women's status can validate national achievements that improve women's status. Such discourse can explore ways to challenge and discredit discriminatory practices in ways that are relevant to, and understood and accepted by, the population in question. "Cross-cultural dialogue" between groups that want to improve the status of women in different cultures can enhance the ability of internal actors to understand and address the nature of women's subordination in their own contexts. He cautioned that cross-cultural dialogue should not press internal actors into understanding and addressing challenges in terms of the experiences of other societies. He explained, "the combination of the processes of internal discourse and cross-cultural dialogue will hopefully deepen and broaden universal cultural consensus on the concept and normative content of women's international right to be free from all forms of discrimination."

Some participants questioned the effectiveness of $\mathrm{An}-\mathrm{Na}^{\prime} \mathrm{im}^{\prime} \mathrm{s}$ approach because religions and cultures are often sources of women's oppression. As a result, they thought that "going secular" is the only option. His response was that in some countries women do not have a secular option because their frames of reference or discourse are religious. As evidence of the possibility of religious or cultural reformation, he pointed to the emergence of women's rights organizations within religious frameworks, such as Women Living under Muslim Laws and Catholics for a Free Choice.

4. Abdullahi An-Na'im, "Islam, Islamic Law and the Dilemma of Cultural Legitimacy for Universal Human Rights," in Asian Perspectives on Human Rights 31 (Claude E. Welch and Virginia Leary eds. 1990). 


\section{MAKING INTERNATIONAL HUMAN RIGHTS LAW GENDER CONSCIOUS}

International human rights and the legal instruments that protect them were developed primarily by men in a male-oriented world. They have not been interpreted in a gender sensitive way that is responsive to women's experiences of injustice. Critical recharacterization of international human rights is needed so that women's distinctive human rights are not marginalized and the implementation of such rights becomes part of the central agenda of human rights work.

Treaty interpretation is not exclusively limited to treaty terms. A text may also be interpreted in a way that advances its goals in contemporaneous circumstances, even if they were not imaginable when the treaty originally was drafted. Moreover, interpretations of human rights treaties by human rights committees and by international, regional, and national courts shall take into account "subsequent practice in the application of the treaty which establishes the agreement of the parties regarding its interpretation." ${ }^{\prime 5}$ As a result, women can interpret the content of treaties on human rights through the "subsequent practice" that adds a gender dimension to those rights.

Human rights may be divided into nondiscrimination rights, civil and political rights, and economic, social and cultural rights. Developing the "subsequent practice" through recharacterization of all three kinds of rights to accommodate the particular nature of women's vulnerabilities to fundamental injustice is required if international human rights law is to be effectively applied to women.

\section{A. Recharacterizing Nondiscrimination Rights}

What constitutes discrimination against women is not a point on which states readily agree. Nonetheless, the legal obligation to eliminate all forms of discrimination against women is a fundamental tenet of international human rights law. Sex is a prohibited ground of discrimination in the Universal Declaration of Human Rights, the International Covenant on Civil and Political Rights (the Political Covenant), the International Covenant on Economic, Social and Cultural Rights (the Economic Covenant) and the three regional human rights conventions, namely the European Convention for the Protection of Human Rights and Fundamental Freedoms (the European

5. Vienna Convention on the Law of Treaties, 23 May 1969, art. 31 (3)(b), 1155 U.N.T.S. $331,340$. 
Convention), the American Convention on Human Rights (the American Convention) and the African Charter on Human and Peoples' Rights (the African Charter).

The Convention on the Elimination of All Forms of Discrimination against Women (the Women's Convention) develops the legal norm on nondiscrimination from a women's perspective. This convention moves from a sexneutral norm that requires equal treatment of men and women, usually measured by how men are treated, to one that recognizes the fact that the particular nature of discrimination against women is worthy of a legal response. The Women's Convention progresses beyond the earlier human rights conventions by addressing the pervasive and systemic nature of discrimination against women, and identifies the need to confront the social causes of women's inequality by addressing "all forms" of discrimination that women suffer. This Convention is thereby able to address the particular nature of women's disadvantages.

An approach to clarifying what constitutes discrimination against women in international human rights law is through the development of General Comments or General Recommendations by the committees established under the different human rights conventions. For example, the Human Rights Committee, established to monitor state compliance with the Political Covenant, has issued General Comment 18 on nondiscrimination based upon the "similarity and difference" model of discrimination. The General Comment states that "not every differentiation of treatment will constitute discrimination, if the criteria for such differentiation are reasonable and objective and if the aim is to achieve a purpose which is legitimate under the Covenant." ${ }^{\prime 6}$

Kathleen Mahoney, University of Calgary Faculty of Law, criticized the "similarity and difference" model of discrimination utilizing the liberal theory of feminism discussed by Charlesworth. The model uses a male standard of equality and renders women copies of their male counterparts. Thus women are forced to argue either that they are the same as men and should be treated the same, that they are different but should be treated as if they were the same, or that they are different and should be accorded special treatment. The model does not allow for questioning the ways in which laws, cultures, or religious traditions have constructed and maintained the disadvantage of women, or the extent to which the institutions are male-defined and built on male conceptions of challenges and harms.

The understanding of discrimination against women evolves through insights, perspective, and empirical information on how women are subordinated by different legal, social, and religious traditions. Standards for 
determining such discrimination must be developed accordingly. As Mahoney explained:

Systemic discrimination or inequality of condition, the most damaging form of discrimination, cannot be addressed via the rule-based "sameness of treatment" approach. Indeed, the use of this model virtually makes systemic disadvantage invisible. By structuring equality around the male comparator, the assumption is made that equality exists and that from time to time, individuals will be discriminated against. The persistent disadvantage women suffer across the board because of societal biases is obscured. The question then becomes, can [international human rights law] support and deliver substantive equality?

Mahoney answered affirmatively, if a test of discrimination is adopted that is based on powerlessness, exclusion, and disadvantage rather than on sameness and difference. A test adopted by the Supreme Court of Canada, ${ }^{7}$ for instance, determines discrimination in terms of disadvantage. If a person is a member of a persistently disadvantaged group and can show that a law, policy, or behavior maintains or worsens that disadvantage, it is discriminatory. She explained that no comparator, male or otherwise, is required. Adoption of the test of "disadvantage," as opposed to the test of "similarity and difference," requires judges to look at women as they are located in the real world in order to determine whether any systemic abuse and deprivation of power that women experience is due to their place in the sexual hierarchy.

Decisions of international and regional human rights tribunals have used the "similarity and difference" test for discrimination, ${ }^{8}$ not the "disadvantage" model that can capture the systemic nature of discrimination against women. The "disadvantage" model of discrimination is more consistent with the object and purpose of the Women's Convention in prohibiting all forms of discrimination against women. The Human Rights Committee, established under the Political Covenant, might be encouraged to adopt the "disadvantage" model, replacing General Comment 18 to help clarify what constitutes discrimination against women. The Committee has reflected on, and further developed, other General Comments. The Committee on the Elimination of Discrimination Against Women (CEDAW), established under the Women's Convention, might also be encouraged to develop a General Recommendation that clarifies its intention to use the "disadvantage" test to determine what constitutes discrimination against women.

7. Andrews v. Law Society of British Columbia (1989) 1 S.C.R. 143.

8. See generally, Anne F. Bayefsky, The Principle of Equality or Non-Discrimination in International Law, 11 Hum. Rts. L.J. 1 (1990). 


\section{B. Recharacterizing Civil and Political Rights}

Participants explored ways to recharacterize civil and political rights for women because, as Charlesworth explained,

the primacy traditionally given to civil and political rights by western international lawyers and philosophers is directed towards protection from men within public life and their relationship with government.

Recharacterization of civil and political rights needs to be done in a variety of ways. For example, the right to life is traditionally referred to as the obligation of states to observe due process of law before capital punishment is imposed. However this interpretation ignores the historic reality of women that persists in many regions of the world. Currently, at least 500,000 women die avoidably each year of pregnancy related causes, such as lack of access to basic obstetric care. ${ }^{9}$

Cecilia Medina, Faculty of Law of the University of Diego Portales, Santiago, Chile, and a researcher at the Netherlands Institute of Human Rights, argued that women's rights to liberty and security are severely constrained by their lack of access to contraceptives. For example, in El Salvador the lack of access to contraceptives causes women to have about twice the number of children they want.

Rhonda Copelon, City University of New York Law School, explored ways to recharacterize the prohibition of torture and inhuman and degrading treatment to accommodate gender-based violence. She argued that genderbased violence is comparable to torture, and that its prohibition ought to be, like prohibition of torture, a principle of jus cogens.

My thesis is that when stripped of privatization, sexism, and sentimentalism, gender based violence - which is brutal, systemic, and structural - must be seen as no less grave than other forms of inhumane and subordinating violence, the prohibition of which has been recognized as jus cogens, or peremptory norms, by the international community. I focus on the jus cogens not to exclude other formulations of gender-based violence, but because, as a normative matter, it embraces the most heinous offenses, precludes exception and binds universally. My argument is not that gender-based violence has attained the status of jus cogens, but rather that it should; and that with a revised process, it could.

Nowak pointed out that if violence against women can be characterized as torture, then states would have universal jurisdiction to prosecute perpetrators of violence against women. Copelon's approach is also designed to have the shock effect of making international lawyers think about why

9. See generally, Rebecca J. Cook, International Protection of Women's Reproductive Rights, 24 N.Y.U. J. Int'l L. \& Pol. 645, 689 (1992). 
gender-specific violations are absent from the jus cogens discourse, the symbolic inner sanctum of international legal rules.

\section{Recharacterizing Economic, Social, and Cultural Rights: The Problem of Structural Adjustment}

Participants, particularly from Africa, were concerned about how structural adjustment programs of the World Bank and the International Monetary Fund (IMF) are negatively affecting the economic, social, and cultural rights of women. ${ }^{10}$ Women, they noted, suffer in a unique and often invisible way. Florence Butegwa, Women in Law and Development, Harare, Zimbabwe, and Akua Kuenyehia, University of Ghana Faculty of Law, described the double injury sustained by women in their countries due to the demands of structural adjustment: injury suffered as citizens of the South and injury suffered as women. Their stories are echoed in the literature on women and structural development. ${ }^{11}$ The findings of this literature show that:

a. The total burden of women's work has increased under recessionary conditions. Structural adjustment programs (SAPs) have reduced social expenditures, rather than increasing them to offset these pressures.

b. Employment creation is weak under SAPs, especially for women.

c. SAPs have done little to address institutional gender inequality in the formal and informal sectors of national economies.

d. In agriculture, the concentration of resources on export crops, which has characterized development and worked to women's disadvantage in the past, has been intensified under SAPs.

e. In both agriculture and industry, women have operated relatively small enterprises and have experienced discrimination because of the bias against smaller scale operations manifest in SAPs.

A consensus emerged at the consultation that human rights have to be rethought to accommodate women's experience of disproportionate disadvantage under structural adjustment programs. The first step to rethinking human rights with reference to structural adjustment is to recognize the double injury it causes women. Once recognized, this injury can be ad-

10. See generally, Special Rapporteur to the Sub-Commission on Prevention of Discrimination and Protection of Minorities in The Realization of Economic, Social and Cultural Rights, U.N. Doc. E/CN.4/Sub.2/1992/16 (1992).

11. See generally, "Bibliography," in Women and Structural Adjustment, Joint Consultative Group on Policy (New York: United Nations Population Fund, 1991). 
dressed in a number of fora in the international system. ${ }^{12}$ An additional approach is to confront the financial institutions themselves. As international actors, the World Bank and the IMF are bound by international law, including human rights norms ${ }^{13}$ and therefore are legally obligated to ensure that women share equally with men in the benefits of their loans.

\section{GUARANTEEING SPECIFIC HUMAN RIGHTS OF WOMEN}

\section{A. The Nationality Problem}

Bert Lockwood, University of Cincinnati College of Law, examined how the Court of Appeal of Botswana in Attorney General v. Unity Dow ${ }^{14}$ applied international human rights principles to the nationality problem. The decision ruled unconstitutional the provision of the 1984 Botswana Citizenship Act which denied a female citizen of Botswana married to a foreigner the right to convey citizenship to her children born in wedlock in Botswana, although a male citizen married to a foreigner could. The Court of Appeal decided that this provision of the Citizenship Act infringed upon Unity Dow's fundamental rights and freedoms, her liberty of movement, and her right to nondiscrimination. The Chief Judge, noting the obligations of Botswana as a signatory to the Universal Declaration of Human Rights and the Declaration on the Elimination of Discrimination against Women, and as a state party to the African Charter, observed that

Botswana is a member of the community of civilised States which has undertaken to abide by certain standards of conduct, and, unless it is impossible to do otherwise, it would be wrong for its Courts to interpret its legislation in a manner which conflicts with the international obligations that Botswana has undertaken. ${ }^{15}$

Lockwood explained that women's disability with regard to citizenship is a problem in many countries, ${ }^{16}$ underscored by the fact that Article 9 of

12. See section V.B., infra, for discussion of the work of the Sub-Commission and the Economic Committee.

13. James C.N. Paul, International Development Agencies, Human Rights and Humane Development Projects, 17 Denv. J. Int'l L. \& Pol'y 67 (1988); Katarina Tomasevski, The World Bank and Human Rights, Yearbook of Human Rights in Developing Countries 75 (M. Nowak ed., 1989)(Oslo: Norwegian Institute of Human Rights).

14. Court of Appeal of Botswana, Civil Appeal No. $4 / 91$ (unreported 1992).

15. Id. at 54. See Judgment No. 30 of 9 Feb. 1983, of the Italian Constitutional Court (La Legislazione Italiana: 1983 , section 14, 28-29) declaring a similar Italian law unconstitutional. U.N. Doc. CEDAW/C/5/Add.62 at 53 (1989) (Italy).

16. For the disabilities of the women with respect to nationality in Gabon, Burkina Faso, and Rwanda, see Economic Commission for Africa, Implementation in Africa of the Convention on the Elimination of All Forms of Discrimination against Women, E.C.A. Doc. E/ECA 
the Women's Convention on nationality is one of the most highly reserved articles. ${ }^{17}$ Women's legal inability to bestow their nationality on their children born of foreign husbands often leaves legitimate children stateless or unable to benefit from attributes of citizenship such as education, health care, and employment. He hoped that this decision might have positive impact on draft legislation to amend such discriminatory nationality laws, such as are now pending in Egypt $^{18}$ and Tunisia and have persuasive authority for cases now pending in Bangladesh and Pakistan, according to Sara Hossein, a legal practitioner from Dhaka, Bangladesh, and Rashida Patel, Legal Aid Centre in Karachi, Pakistan. Another point is that CEDAW, perhaps together with the Children's Committee established under the Convention on the Rights of the Child, might be encouraged to develop a General Recommendation on women's ability to convey nationality to their children, and that it be made an issue during the 1994 International Year of the Family.

\section{B. Discriminatory Personal Law}

In some regions of the world, personal law governs legal relations in all matters regarding marriage, divorce, maintenance, child custody, and guardianship and inheritance, on the basis of religious identity. Christina Cerna, currently on secondment from the Organization of American States to the UN Human Rights Centre in Geneva, was concerned that the persistence of discriminatory personal laws "undermines the universality of international prohibition of discrimination against women."

Kirti Singh, a legal practitioner from New Delhi, explained that the Indian government retains personal law that discriminates against women for reasons of political expediency. The government does not want to interfere with personal matters in the ethnic (usually minority) communities. ${ }^{19} \mathrm{~A}$ case in point is the much discussed Shah Bano decision of the Supreme Court of India. ${ }^{20} \mathrm{~A}$ Muslim man who had divorced his wife of forty years was ordered

CM.13/27, at para. 33 (1987); Report of the Committee on the Elimination of All Forms of Discrimination Against Women, 10th Sess., U.N. Doc. Av46/38, at paras. 131, 237 (1991).

17. Cyprus, Egypt, Korea, Iraq, Jamaica, and Thailand have reserved. See Rebecca J. Cook, Reservations to the Convention on the Elimination of All Forms of Discrimination against Women, 30 Va. J. Int'I L. 643, 693, 714 (1990).

18. Egyptian Gazette, 30 January 1992, explaining that Mamdouh el-Gohari, a member of the People's Assembly, has proposed such a law. Communication Group for the Enhancement of the Status of Women, Legal Rights of Egyptian Women in Theory and Practice, 33-35 (Cairo: Communication Group, 1992).

19. Kirti Singh, "Women and the Reform of Personal Law," in The Hindu and Other: The Question of Identity in India, (G. Pandey ed., forthcoming 1993).

20. Mohammad Ahmed Khan v. Shah Bano, A.I.R. (S.C. 945) (1985). 
to pay monthly maintenance pursuant to a criminal law provision on the prevention of destitution. He objected, arguing that the Muslim personal law requiring him only to return her dowry, which he had done, should prevail over the secular criminal law. His argument was unsuccessful in the Supreme Court of India, but the case triggered a reaction that led to the passage of legislation that overturned the Supreme Court judgment. Singh pointed out that the government, despite the protest of women's groups of all ethnic communities, thought it could not afford to alienate the fundamentalist Muslim community, and so "sealed the fate of millions of Muslim women in India."

Halim addressed the potential for using the Political Covenant and the African Charter to challenge discriminatory aspects of the Sudanese Personal Law for Muslims Act (1991). She said that this Act rendered the meaning of equality "valueless." For example, this Act prevents women from contracting their own marriages, gives men unfettered rights to divorce while requiring women first to prove some sort of specified harm, and prevents women from leaving their homes without permission of their husbands or guardians. Even if a divorce is granted, a woman may "be returned" to her former husband without her consent within three months of divorce. She explained that interpretations of this Act that are consistent with modern realities of women's lives are harshly resisted, even though interpretations of other areas of Islamic law reflecting men's modernization are readily accepted. She pointed out that "women are prisoners of the old interpretations of the Koran and Sunna."

Halim explained that the challenges of applying sexual nondiscrimination provisions of the Political Covenant and the African Charter are formidable:

Muslim women are being told that patriarchy is not what is hindering them, but international law as part of Western ideas is the real obstacle to women. Women should be liberated from Western ideas that are subjecting them to the double burden of domestic and public work. It is argued that there is no need for women to take up the task of liberation. Men will do it for them through the smooth "Islamic" process, if it is kept outside the ambit of secular international law.

Coomaraswamy explained that personal law is usually maintained as part of the politics of communalism, and within that context Shah Bano, and women like her, have no rights. "All men are created equal, but women are bound by the position relegated to them by the different systems of personal law, laws which govern the most important area of their lives, the family." ${ }^{21}$ She pointed out that personal law is the most impervious to change in favor of women's rights:

21. Hensman, Oppression within Oppression: the Dilemma of Muslim Women in India, 22 Thatched Patio (Colombo: International Centre for Ethnic Studies, 1990). 
Here women are divided by community and among themselves about whether a rights discourse is relevant or necessary. Unless we begin to examine law's approach to the family and the private space in greater detail and understand the dynamics more fully with regard to ideological constructions which resist legal change, we will not be able to bring rights home to the family. The task is daunting but necessary. Without equity in the family, there will not be equity in society. ... The law should protect and privilege that kind of family and not any other.

\section{Customary Property Law}

Butegwa addressed the use of the African Charter to redress the disabilities that women face with respect to property under African customary law. In law and in fact, women are denied access to real and personal property, whether it be by discriminatory inheritance, divorce, or customary law. ${ }^{22}$ If one dies without a will, which is generally the case in many African countries, the customary law of one's clan is applied to determine who inherits assets. She explained that the customary law heir is normally the deceased's eldest son, which denies women not only the fruits of the land but also the incidents of land tenure, such as its availability as collateral security for bank loans. Upon divorce, women's claims to matrimonial property are often rejected.

Butegwa said that the African Charter obligates states parties "to ensure that whatever cultural values and practices are permitted by domestic law must comply with the human rights principle of freedom from discrimination on the basis of sex." She recommended that the issue of women's property rights be addressed carefully and pragmatically at the national, regional, and international levels.

At the national level, she said, most governments are not taking the necessary legislative steps to change laws, practices, and customs with regard to women's property rights. Consequently, states parties are failing in their obligations under the Charter to reform sex discriminatory laws. She observed, moreover, that women's groups working to reform discriminatory laws and practices are dismissed by some governments "as misguided elite women aping Western concepts. This situation is compounded by a general lack of awareness among women of the law and the lack of opportunities for them to meet and discuss their legal status and map out strategies." She pointed out that women's rights discourse must occur at the national level, because until women understand the fact that "some customs are illegal under the laws of the country," the discourse might backfire and progress on any women's issues will not be possible.

22. See generally, Symposium edition on women's access to property, Third World Legal Studies Journal (forthcoming 1993). 
With regard to the African Commission on Human and Peoples' Rights, established under the African Charter, Butegwa put it directly: we have "to wake up the Commission." However, she explained that NGOs, women's groups, and the legal profession have "only a cursory knowledge of the African Charter, the Commission, and their relevance and potential in the promotion of women's human rights. It is not surprising, therefore, that the majority has not sought to include the Charter and the Commission in the legal rights awareness programs currently being implemented." As a result, strategies relating to the Charter and the Commission, including improving state reporting on compliance or noncompliance with the Charter's obligations with regard to women, and submitting communications on violations of women's property rights, will be advanced only through considerable effort.

At the international level, Butegwa thought that support is needed from women's rights groups in developed countries to change bilateral and multilateral loan policies. Such women's groups need to lobby their governments to change their aid policies and the loan and grant policies of international institutions such as the World Bank and the International Fund for Agricultural Development (IFAD) to encourage change in recipient states' laws that discriminate against women's property rights. Donor governments and multilateral funders need to ensure that women have equal access with men to the benefits of their loans. This equity can be very difficult to achieve where women have no land to use as collateral security for loans provided by such institutions as IFAD through recipient governments. CEDAW, perhaps with input from the Food and Agricultural Organization, might want to develop a General Recommendation on women and property. This could set out guidelines for reporting states to specify how they have overcome the general disabilities under their customary law for women to own, inherit, or otherwise acquire land.

\section{Reproductive Rights}

Maria Isabel Plata, of Profamilia, Bogota, Colombia, explained how women's groups in Colombia used the Women's Convention to promote equality and reproductive health, observing that "the moment we used an international treaty, the government saw that our claims were legitimate and began to take us seriously." The Colombian women's movement lobbied for incorporation of the principles of the Women's Convention into the 1991 Constitution, and within that context sought new laws and policies for the promotion of women's reproductive health. As a result, the Women's Convention became a part of Colombian law ${ }^{23}$ and some of its principles were adopted

23. The Colombian Presidential Decree No. 1398 of 3 July 1990; Colombian Law 51, 1981. 
into the new Constitution, including a provision on the right to decide freely and responsibly the number of one's children. ${ }^{24}$

Plata explained that the Ministry of Public Health has interpreted the Women's Convention to establish a gender perspective in their health policies that considers "the social discrimination of women as an element which contributes to the ill-health of women. ${ }^{\prime 25}$ A new Ministerial resolution orders all health institutions to ensure women the right to decide all issues that affect their health, their life, and their sexuality, ${ }^{26}$ and guarantees rights "to information and orientation to allow the exercise of free, gratifying, responsible sexuality which can not be tied to maternity." The new policy requires provision of a full range of reproductive health services, including infertility services, safe and effective contraception, integrated treatment for incomplete abortion, and, for example, treatment for menopausal women. The policy emphasizes the need for special attention to high risk women, such as adolescents and victims of violence.

Plata postulated that this new Colombian initiative might provide ideas to other countries that are making serious efforts to comply with the Women's Convention. She recommended that CEDAW consider issuing a General Recommendation that clarifies that the terms "women's health" and "family planning programs" encompass the concepts of "reproductive and sexual health" as used in the new Colombian women's health policy. She urged that CEDAW develop this Recommendation as soon as possible, in part to legitimize the Colombian interpretation of the health provisions of the Women's Convention. Moreover, such a Recommendation would explain that to comply with the Convention, states need to develop comprehensive reproductive health services that "empower women and not use women as means to limit population growth, save the environment, and speed development." She stressed the importance that CEDAW issue such a Recommendation before the 1994 Population Conference because of her concern that at the Conference international thinking on population may revert to the solely demographic mentality of the 1960s, when women's well-being was neglected.

\section{E. Violence against Women}

Joan Fitzpatrick, University of Washington School of Law, Seattle, Washington, explored a range of strategies to combat all forms of violence against women. Forms of violence include domestic violence (murder, rape, and

24. 1991 Colombian Constitution, art. 42.

25. Salud para la Mujer, Mujer para la Salud (Health for Women, Women for Health) Bogota: Ministry of Public Health, May 1992.

26. Colombian Ministry of Public Health, Resolution 1531, 6 March 1992. 
battery) by husbands or other male partners, genital mutilation, gender-based violence by police and security forces (including torture of detained women), gender-based violence against women during armed conflict, gender-based violence against women refugees and asylum seekers, violence associated with prostitution and pornography, violence in the workplace, including sexual harassment, forced pregnancy, forced abortion, and forced sterilization. Copelon explained that:

domestic violence against women is systemic and structural, a mechanism of the patriarchal control of women that is built upon male superiority and female inferiority, sex-stereotyped roles and expectations, and the economic, social and political predominance of men and dependency of women. While the particular cultural embodiments of patriarchal thinking vary between different cultures, there appears to be an astounding convergence of cultures in regard to the basic tenets of patriarchy and the permissibility, if not necessity, of violence as a mechanism of enforcing that system.

No issue raises the inherent limitation of the gender-neutral approach to equality more acutely than domestic violence against women. Fitzpatrick pointed out that a "special treatment" approach is needed, as opposed to formal equality, to recognize that women exist in concrete contexts. This has been suggested in the CEDAW Recommendation 19 on Violence against Women, the Draft Declaration on the Elimination of Violence against Women, the European Parliament and the draft Inter-American Convention on the Prevention, Punishment and Eradication of Violence against Women, as well as the UN Crime Prevention and Criminal Justice Branch. Fitzpatrick stressed that victims of domestic violence exist under pressures that are not felt by other crime victims. Battered women often lack the economic, social, and emotional means to leave their batterers. Not employed outside the home, they have no financial resources at their disposal. They have been socialized to define themselves primarily through their relationships with men and cannot face leaving these relationships. This points to the need for "special treatment" in such forms, for instance, as battered women's shelters.

Participants struggled with the question about whether domestic violence is better characterized as a violation of the civil and political right to liberty and security, or as a violation of the nondiscrimination right to equal resources for crime control. The former characterization may be more effective in the long term to integrate women's experiences of injustice into the concepts of international human rights law, but the latter may enjoy greater short term success precisely because it poses less of a fundamental challenge to patriarchal systems.

Participants stressed the importance of strategies that will enhance international standards of prohibition of violence against women, such as the CEDAW General Recommendation 19, and means that will facilitate the enforcement of standards, such as the Communication procedures before the Commission on Status of Women and the individual complaint procedure 
before the Committee against Torture, established under the Convention against Torture and Other Cruel, Inhuman or Degrading Treatment or Punishment. ${ }^{27}$ They also explored strategies that would bring the issue of violence against women into the main stream of human rights work, such as the international effort to put the issue on the agenda of the 1993 International Conference on Human Rights, to be held in Vienna.

\section{WORKING WITH WHAT WE HAVE: MAKING INTERNATIONAL HUMAN RIGHTS LAW MORE EFFECTIVE FOR WOMEN}

\section{A. State Responsibility for Violation of Women's Rights}

The international law of state responsibility makes a state legally accountable for breaches of international obligations that are attributable or imputable to the state. In other words, only a state and its agents can commit a human rights violation. Non-state actors are not generally accountable under international human rights law, but the state may sometimes be held responsible for related human rights violations. Modern development of international human rights law through state adherence to multilateral human rights conventions has enhanced prospects of state accountability and women may be able to turn these developments to their advantage.

Ken Roth, Human Rights Watch, explored the feasibility of applying different theories of state accountability developed in other areas of international human rights law to violations of women's human rights. The international human rights movement has used three distinct theories of government accountability: government agency, government complicity by failure to act, and government responsibility for the unequal application of the law. Roth argued that the same theories of governmental accountability that were invoked for state complicity in various forms of violence by nonstate actors $^{28}$ should be applied to domestic violence against women.

Comparing the first and second theories, Roth stressed the limits of the theory of government complicity. Whereas the theory of government agency treats an act of private violence as the act of a government agent and therefore requires that such violence be ended outright, the theory of governmental complicity simply requires that the state not condone private violence. Where a state is doing the bare minimum in combatting domestic violence to escape charges of complicity, an unequal application theory allows insistence on

27. Andrew Byrnes, "The Committee Against Torture," in The United Nations and Human Rights: A Critical Appraisal 509, 519-20 (Philip Alston ed., 1992).

28. See Velasquez Rodriguez v. Honduras, supra note 3; Herrera Rubio v. Colombia, supra note 3 . 
greater diligence as a matter of international human rights law. International law can demand that a state's efforts to combat domestic violence be at least on a par with its efforts to fight comparable forms of violent crime.

In regard to the third theory, Roth argued that the nondiscrimination provisions of the Political Covenant can also be used to require that the same level of state resources used to enforce criminal laws against private acts of violence be devoted to crimes against women. That is, crimes against women, under the nondiscrimination theory of accountability, need to receive at least as thorough an investigation and as vigorous a prosecution as crimes against men. Roth explained that "lesser attention constitutes not only a violation of the antidiscrimination provisions of the Covenant but also evidence of the complicity needed to make out a substantive violation." ${ }^{29}$

Some participants thought that the nondiscrimination theory of state responsibility is a useful first step. The nonenforcement of laws to protect women's rights was consistently discussed as a reason for women's continued subordination. The nondiscrimination theory of accountability could require governments to stop neglecting their duties with respect to women and actually implement laws to protect women's rights. The theory also might require the domestic criminal justice system and the international human rights system at least to explore the relative lack of enforcement of criminal laws against those who victimize women, for instance through wife-beating.

Questions were raised whether this approach would suffice to combat violence against women as it has the same shortcomings as the "similarity and difference" model of discrimination. Halim questioned whether it would be sufficient in Sudan to require enforcement of a rarely applied law criminalizing female circumcision. Butegwa observed that comparing this form of violence to other forms of criminal violence committed against other social groups might obscure the systemic nature of violence against women. The consensus was that further work is needed on theories of state responsibility to hold the state accountable for failures of prevention, investigation, and punishment of violations of women's rights.

\section{B. International Protection}

Byrnes explained that the methods of international protection of women's human rights range from recourse to limited international judicial or quasi-

29. For further exploration of the application of these theories of state responsibility for the violations of women's rights, see Human Rights Watch, Criminal Injustice: Violence Against Women in Brazil (1991); Human Rights Watch, Double Jeopardy: Police Abuse of Women in Pakistan (1992); Human Rights Watch, Punishing the Victim: Rape and Mistreatment of Asian Maids in Kuwait (1992). 
judicial processes to the application of broader means of furthering states parties' accountability, such as through reporting requirements. ${ }^{30} \mathrm{He}$ noted that the application of human rights norms to national laws and practices that are alleged to violate women's rights must be approached in a variety of ways. Any one method may be fragile and inadequate, but there are cumulative ways in which, in Romany's words, "women can make rights their own." Potential approaches will be examined below from the perspective of different protective bodies that derive their authority from separate human rights treaties or from the UN Charter.

\section{Treaty based Bodies}

Byrnes explained that all major human rights treaties provide for a system of reporting. State parties are required to make regular reports to the responsible supervisory bodies on the steps taken to implement their obligations and the difficulties they have experienced in doing so. Reports are examined by the relevant treaty bodies in the presence of representatives of the states concerned. All Committees receive information informally from NGOs, which they may use in their questioning. The examination process, he points out, can provide an occasion for exerting pressure on states. If members of a supervisory body are strongly critical of a state or express the view that the state has not discharged its obligations under the treaty, this can put pressure on a government, particularly if the proceedings receive international or national publicity.

All human rights treaty bodies, Byrnes explained, have the power to make General Comments or General Recommendations. These detailed comments can be particularly useful for elaborating the specific content of broadly worded treaty guarantees, and may be helpful in domestic, political, or even judicial contexts. He cautioned that, with the exception of CEDAW, gender plays a relatively minor role in the General Comments of most committees. Nonetheless they are grateful for, and in need of, expert input from NGOs, and thus this process is available for advancement of women's rights.

Byrnes pointed out that national NGOs, which might be able to exploit the reporting procedure, may know little about the procedure, the appropriate format for submission of material, and how most effectively to lobby members of a committee or to generate publicity. Every government needs to be encouraged to publish treaty reports in the local language, to share them as a matter of course with the relevant NGOs, and even debate them in the national parliament.

30. For an overview of these procedures, see "International Procedures for Complaints of Human Rights Violations," app. IV, in Commonwealth Human Rights Initiative, Put Our World to Rights: Towards a Commonwealth Human Rights Strategy (1991); Cuide to International Human Rights Practice (Hurst Hannum ed., 1992). 
The Human Rights Committee, established under the Political Covenant, has an individual complaint procedure. This procedure is available to individuals in nearly seventy countries that have ratified the Optional Protocol to the Political Covenant. Under this procedure, the Human Rights Committee has decided a case on a woman's right to enjoy her own culture, ${ }^{31}$ and a few sexual nondiscrimination cases.32 From a women's perspective, the jurisprudence developed by this Committee is limited by the adoption of the "similarity and difference" test of discrimination. ${ }^{33}$

The Human Rights Committee is willing to scrutinize allegations of discrimination in violation of rights recognized by, for example, the Economic Covenant and the Women's Convention. ${ }^{34}$ This enables women in those countries to bring complaints about violations of their rights of equal entitlements protected by the Economic Covenant and, for example, the Women's Convention, provided that those countries are parties to the lattermentioned conventions.

The Committee on the Elimination of Discrimination against Women (CEDAW) monitors state parties' compliance with the Women's Convention. ${ }^{35}$ Norma Forde, Faculty of Law of the University of the West Indies (Barbados) and a member of CEDAW, noted that the work of CEDAW is far more effective when CEDAW members have recourse to sources of information in addition to data contained in reports of state parties. Accordingly, she explained, CEDAW has requested the Division for the Advancement of Women at the UN Secretariat in Vienna to compile statistics garnered from official UN sources relevant to members' reports. CEDAW has also requested UN specialized agencies to provide it with relevant information and encourages NGOs to send them information, particularly on major problems facing women in the reporting countries.

31. Lovelace v. Canada, Communication No. 24/1977, U.N. Doc. A/36/40 (1981); U.N. Doc. CCPR/C/OP/1, at 83 (1985) (law requiring that only Indian women, but not Indian men, lose their status and rights when they married a non-Indian man, held to be a denial of their right to enjoy their own culture).

32. Aumeeruddy-Cziffra et al. v. Mauritius, Communication No. 35/1978, U.N. Doc. AV36/40 (1981) (law limiting residency status of foreign spouses of Mauritian women but not similarly situated Mauritian men held discriminatory); Ato del Avellanal v. Peru, Communication No. 202/1986, U.N. Doc. A44/40 (1989) (women held to have equality before the courts).

33. See Section III.A, supra.

34. Broeks v. The Netherlands, Communications No. 172/1984, 42 U.N. GAOR Supp. (No. 40 ) at 139, U.N. Doc. A $42 / 40$ (1987) (same entitlements to social security benefits for women required as similarly situated men); Zwaan-de Vries v. The Netherlands, Communication No. 182/1984, 42 U.N. GAOR Supp. (No. 40) at 160, U.N. Doc. A 42/40 (1987) (same holding as in Broeks); But see, Vos v. The Netherlands, Communication No. 218/1986, A $44 / 40$ (1989) (unequal disability allowance justified).

35. To obtain copies of the reports, which are available in the official languages of the United Nations (English, French, Spanish, Arabic, Chinese, and Russian), write to the Division for the Advancement of Women, United Nations Office at Vienna, P.O. Box 500, A-1400 Vienna, Austria. See generally, Annual Report on the CEDAW meetings of the International Women's Rights Action Watch, Humphrey Institute, University of Minnesota, Minneapolis. 
The Committee on the Elimination of Racial Discrimination, established under the International Convention for the Elimination of All Forms of Racial Discrimination (the Race Convention), provides an important forum for raising issues of discrimination against women belonging to racial minorities. ${ }^{36}$ Participants were concerned that women of minority communities are subject to discrimination and violence as members of their communities, and additional discrimination and violence as women. Moreover, in Hossein's words, "they are further condemned to carry the brunt of resistance to change by conforming to the discriminatory traditions and customs practised by their community."

The Committee on Economic, Social and Cultural Rights (the Economic Committee) monitors state parties' compliance with the Economic Covenant. The Committee has developed some innovative working methods to enhance its normative functions, including formally receiving written submissions from NGOs, holding annual "general discussions" on certain rights contained in the Economic Covenant, and involving "recognized experts" to provide oral testimony during these discussions. ${ }^{37}$ These methods provide significant opportunities to develop a feminist content to economic, social, and cultural rights.

Important research shows how economic development has exacerbated women's marginalization, despite programmatic initiatives to integrate women into development. ${ }^{38}$ The Economic Committee might invite "recognized experts" during the annual "general discussions," in order to explain why some of these programs have not been successful in improving women's actual status, and what implications these insights might have for the effective application of economic, social and cultural rights. Discussions with these experts might result in a General Comment on how state parties might more effectively ensure that women enjoy rights protected by the Economic Covenant.

\section{Charter-based Bodies}

The UN Commission on the Status of Women (the Commission) has the authority to review communications sent to it by individuals and organizations in order to identify those that appear to reveal "a consistent pattern of reliably attested injustice and discriminatory practices against

36. Yilmaz-Dogan v. The Netherlands, Communication No. 1/1984, U.N. Doc. CERD/C/36/ D/1 (1984) (termination from job in a textile factory of a Turkish woman residing in The Netherlands racially discriminatory).

37. Scott Leckie, An Overview and Appraisal of the Fifth Session of the UN Committee on Economic, Social and Cultural Rights, 13 Hum. Rts. Q. 545, 546 (1991).

38. See generally, Persistent Inequalities: Women and World Development, (lrene Tinker ed., 1990); Anne Marie Goetz, "Feminism and the Claim to Know: Contradictions in Feminist Approaches to Women and Development," in Cender and International Relations 13357 (Rebecca Grant \& Kathleen Newland eds., 1991). 
women.."39 The Commission is authorized under this procedure to examine communications as a source of information only for purposes of identifying general trends and patterns of violations against women. The Commission can make general recommendations to the Economic and Social Council (ECOSOC) on the action ECOSOC may wish to take on trends and patterns, but the Commission is not authorized to take any other action. ${ }^{40}$ Byrnes suggested that the Commission should be encouraged to improve this procedure for the purposes of identifying specific situations in which individuals need redress, or inequitable country situations, and conducting thorough studies of them.

The Commission on the Status of Women has input to the 1993 International Human Rights Conference, the 1993 International Year for the World's Indigenous People, the 1994 Population and Development Conference, the 1994 International Year of the Family, and the UN Decade of International Law 1990-99. The Commission is planning the 1995 Women's Conference to be held in Beijing, China. It might be encouraged to appoint Working Groups or Special Rapporteurs on such cross-over themes as women's rights and indigenous rights, the impact of structural adjustment on the exercise of women's rights, and women's rights in the family and in family planning programs. The Working Groups or the Special Rapporteurs could report during these international conferences and years.

The Sub-Commission on the Prevention of Discrimination and Protection of Minorities (the Sub-Commission) has used Working Groups and Special Rapporteurs to address alleged human rights violations where women are particularly vulnerable. The Sub-Commission's Working Group on Contemporary Forms of Slavery has developed a Plan of Action for governments on child prostitution and child pornography and a Plan for the Prevention of Traffic in Persons and the Exploitation of the Prostitution of Others. ${ }^{41}$ The Sub-Commission has created a Special Rapporteur on Traditional Practices Affecting the Health of Women and Children. ${ }^{42}$

The Sub-Commission is also considering the role and equal participation of women in development as a sub-issue of the New International Economic Order and the promotion of human rights, and is considering the prevention of discrimination and protection of women as a sub-issue of the program

39. ECOSOC Res. 1983/27 of 26 May 1983.

40. See generally, Report of the Secretary General, Monitoring the Implementation of the Nairobi Forward-Looking Strategies for the Advancement of Women: Examining Existing Mechanisms for Communications of the Status of Women, U.N. Doc. E/CN.6/1991/10 (1990).

41. See generally, Report of the Working Group on Contemporary Forms of Slavery, 15th Sess., U.N. Doc. E/CN.4/Sub.2/1990/44 (1990).

42. See generally, Report of the Special Rapporteur on Traditional Practices Affecting the Health of Women and Children, U.N. Doc. E/CN.4/Sub.2/1991/6 (1991). 
on Promotion, Protection and Restoration of Human Rights at National, Regional and International Levels. ${ }^{43}$

The Resolution 1503 procedure requires that the communications before the Sub-Commission reveal a consistent pattern of gross violations of human rights. However, Byrnes concluded that this procedure has made little contribution to addressing issues of sex discrimination or violations of human rights that have a significant gender dimension.

\section{Regional Protection}

Regional human rights conventions have been applied sparingly to violations of women's human rights. The European Court of Human Rights has heard five cases concerning the violation of women's rights, ${ }^{44}$ and the inter-American Court of Human Rights also has heard one case. ${ }^{45}$ In addition, the European Commission of Human Rights, the Inter-American Commission of Human Rights, and the Court of Justice of the European Communities, established under the Treaty of Rome, have all considered complaints concerning women's legal status. ${ }^{46}$ And yet work is still possible at regional levels, beyond specifically judicial approaches, to enhance the norm of the prohibition of all forms of discrimination against women. Advocacy at the regional level provides opportunities that do not necessarily exist at the international level. Geographic proximity, cultural similarity, and economic interdependence can all facilitate the development and application of human

43. See generally, UN Secretary-General, Annotations to the Provisional Agenda of the Fortythird Session of the Sub-Commission on Prevention of Discrimination and Protection of Minorities, U.N. Doc. E/CN.4/Sub.2/1991/1/Add.1 (1991).

44. See supra note 2; Marckx v. Belgium, 31 Eur. Ct. H.R. (Ser. A) (1979) (law requiring unmarried mothers to register and officially adopt their own child violates privacy and nondiscrimination rights); Abdulaziz, Cabales \& Balkandali v. United Kingdom, 94 Eur. Ct. H.R. (Ser. A) (1985) (law requiring women, but not men, lawfully settled in UK to meet certain requirements before their foreign husbands could join them violates privacy and nondiscrimination rights); Open Door and Dublin Well Woman v. Ireland, 64/1991/316/ 387-388, 29 Oct. 1992 (governmental ban on counselling where to find abortions abroad violates rights to impart and receive information); see generally Buquicchio-Boer, Sexual Equality in the European Convention on Human Rights: A Survey of Case Law, Council of Europe, Doc. EG(89) 3 (1989).

45. Proposed Amendment to the Naturalization Provisions of the Constitution of Costa Rica, Advisory Opinion OC-4/84 of 19 Jan. 1984, (Ser. A., No. 4) (1984) (proposed amendment to Costa Rican Constitution distinguishing between foreign men and women marrying Costa Rican citizens held discriminatory); see generally Cecilia Medina, "Women's Rights as Human Rights: Latin American Countries and the Organization of American States (OAS)," in Women, Feminist Identity and Society in the 1980s 63-79 (Myriam DiazDiocaretz \& Iris M. Zavala eds., 1985).

46. See generally, Rebecca J. Cook, International Human Rights Law Concerning Women: Case Notes and Comments, 23 Vand. J. Transnat'I L. 779 (1990); Sacha Prechal and Noreen Burrows, Gender Discrimination Law of the European Community (1990). 
rights standards. ${ }^{47}$ Regional systems can provide opportunities to establish legitimacy of women's human rights within the cultures of the region.

According to Anja-Riita Ketokoski, Finnish Ministry for Foreign Affairs and a member of the Committee for the Equality between Women and Men of the Council of Europe, a European heritage is evolving through many legal and extra-legal means to attain "parity democracy in decision making." She advised women to concentrate their efforts on the institutions in which they can most meaningfully participate. In the European human rights system, for instance, Ketokoski characterized the Conference on Security and Cooperation in Europe and the European Economic Community as less womanfriendly than the Council of Europe and the Nordic Council of Ministers, where recipes for the protection and promotion of women's rights are exchanged and refined with regularity.

Chaloka Beyani, a Zambian research fellow at Wolfson College, Oxford, stressed the importance of using the sexual equality provisions of the African Charter, because most national constitutions in Africa do not include sex as a prohibited ground of discrimination. He explained that the African Charter requires the elimination of all forms of discrimination against women, as stipulated in international declarations and conventions, including the Women's Convention.

He observed that the African Charter obliges the African Commission to draw inspiration from the international law of human rights and international human rights instruments, which enables it to establish a collaborative relationship with CEDAW. Collaboration is appropriate because some African states are parties to both the African Charter and the Women's Convention. Furthermore, collaboration would help the African Commission to undertake an investigation into ways and means of protecting women's rights in Africa, which Beyani considered to be a top priority for the African Commission.

Medina agreed with Beyani that it is important to broaden the basis of comparison. She explained that the Inter-American Commission on Human Rights and the Inter-American Court of Human Rights have the authority to monitor the conduct of states with regard not only to the American Convention but also to all other obligations in the field of human rights, including the Women's Convention. She observed that the Inter-American Commission on Human Rights might be assisted in its task of protecting and promoting the human rights of women if it had working ties with the Inter-American Commission on Women.

The Commission on Women has the power to consult the Inter-American Court on matters concerning the application of human rights treaties to

47. Burns H. Weston, Robin Ann Lukes, \& Kelly Hnatt, Regional Human Rights Regimes: $A$ Comparison and Appraisal, 20 Vand. J. Transnat'] L. 585, 589-90 (1987). 
women. The Commission could seek an Advisory Opinion from the Court on the permissibility of reservations to the Women's Convention filed by countries that are members of the Organization of American States. She cautioned, however, that a prerequisite of effective use of the Inter-American system for the protection of human rights of women is education and training of women's groups, judges, and lawyers.

\section{Domestic Protection}

Domestic protection of women's human rights is usually the first line of defense for women. Anne Bayefsky, University of Ottawa Faculty of Law, explained that the international machinery for the protection of human rights is subsidiary to the national machinery. A general rule in international law is that domestic remedies (where they exist) must be exhausted before international or regional tribunals will take up a case. This rule requires the state to afford a prior opportunity to redress alleged violations by its own means and within the framework of its domestic legal system.

Bayefsky noted that there are alternative general theories about the relationship between municipal law and international law, and one has to look to municipal law to determine which theory is embraced by each country: ${ }^{48}$

1. The adoption theory states that international law is part of domestic law automatically, without an act of incorporation, except where it conflicts with statutory law or well-established rules of the common law.

2. The transformation theory states that international law is part of domestic law only when it has been incorporated into domestic law.

When human rights treaties are directly adopted into internal law, they may be invoked before and enforced by municipal courts and administrative authorities. Domestic protection of women's rights can be strengthened in states that favor the latter theory by the transformation of international human rights treaties, either in whole or in part, through legislation or presidential decrees.

Hossain explored the possibility of using the Women's Convention to challenge discriminatory aspects of personal laws and further to define the content of the right to sexual nondiscrimination in domestic law. She explained that personal laws "sanction discrimination against women through practices such as polygamy, limited rights to divorce, guardianship, and custody." Use of the sexual nondiscrimination provision of the Bangladesh

48. Information on domestic legislation enacted pursuant to human rights conventions can be found in the reports of states parties submitted to the human rights treaty bodies. 
Constitution to challenge discriminatory aspects of personal laws is limited by the fact that the constitutional guarantee extends only to the state and public sphere.

Hossain argued that the Women's Convention requires Bangladesh, as a state party, to eliminate all forms of discrimination against women by any person and to ensure equality with respect to marriage and family relations. She contended that Bangladeshi reservations to the Women's Convention are impermissible as being incompatible with the object and purpose of the Convention. Bangladesh therefore must implement the entire Convention without delay. She considered that:

it is imperative to insist upon the incorporation of universally accepted norms of nondiscrimination in every sphere, which prioritize the rights of the individual above those of the traditionally defined community. State sanction of such norms would assist in the process of their legitimization, critical in a situation where traditional and customary notions of women's roles hold sway. Popular legitimization of these principles would provide leverage not only for substantive internal reform of each community's laws but perhaps also for eventual overhaul of the system.

\section{CONCLUSION: COMMON DENOMINATORS}

Participants at the consultation were focused on the goal of achieving women's equal human rights, and the role that international law could play in achieving that end. They identified certain basic strategies that should be developed in order to equip activists inspired by the ideal of making women's equality a reality. Participants agreed upon their common destination, but also agreed that they must take different pathways towards their goal because they were starting from different origins. The consultation was seen as providing ideas for reform that could move along pathways from different origins towards the common destination.

Prerequisites to reform included improved education and training in human rights law and processes, provision of legal services for women's empowerment, development of capacities to research facts and publicize findings, and promotion of the feminist presence on human rights committees, courts, and commissions.

Mona Rishmawi, International Commission of Jurists in Geneva, Switzerland, thought that training for judges and personnel providing legal services for women was extremely important. She explained that domestic judges usually are unfamiliar with international law in general and international human rights law in particular. Training is important to show judges how this body of law can be used domestically and to make this law more accessible to them. She also recommended legal services and social counselling for women because, without it, women who are economically de- 
pendent on their husbands will not have the means to bring cases.

With training on women's international human rights for judges and legal aid for women, Plata suggested it might be possible to file individual communications from several countries of a region with the regional human rights commission, such as the Inter-American Commission of Human Rights, on a particular form of women's subordination, such as the nonenforcement of criminal laws against perpetrators of domestic violence.

Most committees, courts, and commissions are composed of men, a fact that may significantly reduce the chances of success of innovative claims about the systemic nature of women's subordination. The feminist presence in domestic, regional, and international human rights tribunals has to be increased to ensure that women's concerns are addressed.

One of the themes that emerged from the consultation was that effective application of women's international human rights depends on both vertical and horizontal interactions. Vertical interaction involves both working down and working up. Working down refers to the process that Byrnes called "bringing the international back home," meaning increasing the use of women's international human rights at the domestic level in legal and political contexts. Working up means introducing into international human rights law legal developments favorable to women, such as the Andrews decision and the diversity of women's experiences within different cultures.

Horizontal interaction refers to the exchange of experiences among regional human rights systems and among national courts or systems of the same region. For example, Beyani believed that the experience gained in the Inter-American system is particularly useful for application of the African Charter. Lockwood spoke of the importance of NGOs filing amicus curiae briefs in cases that might have important implications for women fighting similar causes in other countries, as was done by the Cincinnati-based Urban Morgan Institute in the Unity Dow case. States do not have to wait for laws and practices to be challenged or for human rights tribunals to consider alleged violations of rights before moving to protect women. They can begin by changing their laws and policies that are similar to those of other countries that have been successfully challenged under human rights conventions to which they are party.

To be effective, many recommendations made during the consultation depend on the political will of the state. The fact that relationships between women and the state not only vary from country to country but also are evolving must not be forgotten. Ketokoski described the Nordic states as increasingly allied with women, whereas Coomaraswamy explained that Asian women are alienated from the state. Brigitte Mabandla, Community Law Centre of the University of the Western Cape, South Africa, spoke of the importance of mobilizing women to ensure that their interests are protected by the new South African Constitution. Karen Knop, University of Toronto Faculty of Law, discussed the different approaches that women might 
take to the institution of the state, including reconstituting state sovereignty so as to enable women to participate directly in the evolution of international law on issues directly and indirectly affecting women.

The consultation showed that among lawyers there must be better interaction in the work of theoreticians and practitioners. Academic lawyers working on the integration of women's human rights into the universal human rights movement must be aware of how theoretical concepts depend on applicability according to the rules of practice and needs of documentation of human rights committees, courts, and commissions. Legal practitioners must recognize that their work will be enriched by awareness of feminist analysis and by the relation between the practical goals and the transcending evolution of the human rights movement.

The nature and extent of violations of women's international human rights continue to be cruel and pervasive. In many countries, violations remain not simply unremedied, but unnoticed as discriminatory or as an affront to human dignity. This widespread failure to honor international obligations poses a challenge to the credibility, universality, and justice of international human rights law. 